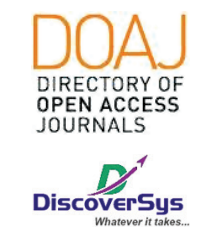

Published by DiscoverSys

\section{Aktivitas secara in vitro dan in vivo kombinasi ekstrak daun kelor (Moringa oleifera lam.) dan pegagan (Centella asiatica (I.). Urb.) sebagai gel anti jerawat}

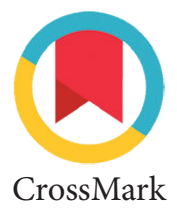

\author{
Ninik Setya Hastuti, ${ }^{*}{ }^{*}$ Shelly Taurhesia, ${ }^{2}$ Agung Eru Wibowo ${ }^{3}$
}

\section{ABSTRACT}

Background: Acne is a skin problem that is common in everyday life. Expressions of acne can cause psychological problems because of appearance. Moringa leaf extract and herbs contain alkaloid compounds, flavonoids, saponins, tannins and phenolics that can be used as antibacterial, reduce inflammation, reduce sebum glands and moisturize the skin. The purpose of this study was to conduct an in vitro and in vivo analysis of gel activity in combination of Moringa Oleifera L. leaf extract and Centella asiatica (L.). Urb.) Herb or KEKP gel as an anti-acne gel. Method: Activities carried out in vitro with an antibacterial effect on P. acnes, in vivo are carried out by clinical observation and measurement of sebum secretion. The gel contains the same combination of extracts.
Twelve volunteers who met the inclusion and exclusion criteria followed the in vivo test to determine the safety and benefits of KEKP gel.

Results: At a concentration of $0.78 \%$ dilution shows a diameter of $10.4 \mathrm{~mm}$ inhibitory power. Medikline as a positive control gives better results compared to KEKP gel with a minimum inhibition diameter of $16.6 \mathrm{~mm}$. Clinical improvement was assessed by reduced signs of inflammation, the number of papules, pustules, nodules and changes in sebum levels measured using a skin analysis tool.

Conclusion: The results showed that KEKP antifungal gel invitro had antibacterial activity, and in vivo showed real clinical differences

Keywords: Moringa oleifera L., Centella asiatica (L). Urban, anti-acne gel, antibacterial, skin analysis.

Cite This Article: Hastuti, N.S., Taurhesia, S., Wibowo, A.E. 2019. Aktivitas secara in vitro dan in vivo kombinasi ekstrak daun kelor (Moringa oleifera Iam.) dan pegagan (Centella asiatica (I.). Urb.) sebagai gel anti jerawat. Intisari Sains Medis 10(3): 629-636. D0I: 10.15562/ism.v10i3.351

\title{
ABSTRAK
}

Latar Belakang: Jerawat merupakan salah satu masalah kulit yang umum dijumpai dalam kehidupan sehari - hari. Masalah jerawat dapat menimbulkan masalah psikologis karena mengganggu penampilan. Ekstrak daun kelor dan herba pegagan mengandung senyawa alkaloid, flavonoid, saponin, tannin dan fenolik yang dapat berperan sebagai antibakteri, mengurangi inflamasi, mengurangi kelenjar sebum dan melembabkan kulit. Tujuan penelitian ini melakukan analisa secara in vitro dan in vivo aktivitas gel kombinasi ekstrak daun kelor (Moringa oleifera L.) dan herba pegagan (Centella asiatica (L.). Urb.) atau gel KEKP sebagai gel antijerawat.

Metode: Aktivitas antijerawat diuji secara in vitro dengan menguji efek antibakteri terhadap $P$. acnes, aktivitas secara invivo dilakukan dengan pengamatan klinis dan pengukuran sekresi sebum. Gel berisi kombinasi ekstrak dengan berat yang sama. Dua belas sukarelawan yang memenuhi kriteria inklusi dan eksklusi mengikuti uji secara in vivo untuk mengetahui keamanan dan manfaat gel KEKP.

Hasil: Pada konsentrasi pengenceran 0,78\% menunjukkan diameter daya hambat 10,4 mm. Medikline sebagai kontrol positifmemberikan hasil yang lebih baik jika dibandingkan gel KEKP dengan diameter hambat minimal sebesar $16,6 \mathrm{~mm}$. Perbaikan secara klinis dinilai dari berkurangnya tanda inflamasi, jumlah papul, pustule, nodul dan perubahan kadar sebum yang diukur menggunakan alat skin analysis.

Simpulan: Hasil penelitian menunjukkan gel antijerawat KEKP secara invitro memiliki aktivitas antibakteri, dan secara invivo menunjukkan perbedaan klinis yang nyata.

\section{Indonesia}

3Pusat Penelitian IImu Pengetahuan dan Teknologi Indonesia

\section{*Korespondensi:}

Ninik Setya Hastuti; Fakultas

Farmasi, Universitas Pancasila, Jakarta;

drniniksetya@gmail.com

Diterima: 11-11-2018

Disetujui: 10-10-2019

Diterbitkan: 01-12-2019
Kata kunci: Moringa oleifera L., Centella asiatica (L). Urban, gel antijerawat, antibakteri, analisis kulit

Cite Pasal Ini: Hastuti, N.S., Taurhesia, S., Wibowo, A.E. 2019. Aktivitas secara in vitro dan in vivo kombinasi ekstrak daun kelor (Moringa oleifera lam.) dan pegagan (Centella asiatica (I.). Urb.) sebagai gel anti jerawat. Intisari Sains Medis 10(3): 629-636. D0I: 10.15562/ism.v10i3.351

\section{PENDAHULUAN}

Jerawat merupakan salah satu masalah kulit yang umum dijumpai dalam kehidupan sehari - hari. Meskipun jerawat bukan penyakit yang menyebabkan kematian dan gangguan kesehatan yang serius, pada kenyataannya masalah psikologis sering dialami oleh mereka yang mempunyai masalah jerawat, seperti menyebabkan depresi atau hilangnya rasa percaya diri seseorang. ${ }^{1,2}$ Penyebab jerawat sampai dengan saat ini belum diketahui dengan pasti, tetapi empat faktor yaitu hiperkeratinisasi 
folikel, hipersekresi sebum, proses inflamasi kronis pada kelenjar sebasea dan kolonisasi bakteri Propionibacterium acne telah diyakini berkontribusi besar menjadi penyebab jerawat. Hal ini dikarenakan bakteri $P$. acnesmampu memproduksi faktor kemotaktik yang menyebabkan terjadinya akumulasi netrofil pada daerah lesi jerawat. Setelah terjadi fagositosis oleh netrofil, enzim lisosom dan ROS akan dilepas dan keadaan ini mampu memprovokasi respon imun dan reaksi inflamasi. ${ }^{3}$ Sampai saat ini, belum ada penanganan jerawat yang paling tepat. Pemberian antibiotik terbukti efektif untuk mengatasi jerawat, namun resistensi antibiotik yang semakin meluas menjadi masalah penting diseluruh dunia., ${ }^{4,5}$ Bahan alam yang mempunyai efek antibiotik dapat menjadi jawaban atas masalah tersebut diantaranya adalah tanaman kelor (Moringa oleifera Lam.) dan pegagan (Centella asiatica (L.).Urb.). Selain efek sebagai antibiotik, kombinasi kedua tanaman tersebut diduga mampu mempercepat penyembuhan jerawat dan memperbaiki kondisi sebum.

Tanaman kelor (Moringa oleifera Lam.) telah banyak diteliti dan terbukti mempunyai banyak manfaat baik daun, bunga maupun bijinya. Selain kaya dengan kandungan gizinya, ternyata mampu memberikan hasil yang baik untuk pengobatan antibakteri baik gram positif dan negatif, antiinflamasi, antiulser, dan anti jamur. ${ }^{6,7,8,9}$ Pada penelitian yang telah dilakukan sebelumnya, senyawa yang terkandung dalam ekstrak daun kelor telah terbukti mampu meningkatkan kelembaban kulit, berperan pula sebagai anti aging karena kandungan anti oksidannya yang tinggi dan mampu mengurangi sekresi kelenjar sebum sehingga dapat dimanfaatkan sebagai alternatif pengobatan jerawat. ${ }^{10}$

Pegagan (Centella asiatica (L.).Urb.) dalam banyak penelitian juga menunjukkan aktivitas sebagai antibakteri baik gram positif dan beberapa gram negatif. ${ }^{11,12}$ Mekanisme kerja pegagan yaitu melalui kemampuan menstimulasi proliferasi fibroblast intraseluler, meningkatkan sintesa kolagen pada jaringan kulit dan juga meningkatkan kekuatan tarikan kulit yang baru terbentuk serta menghambat fase inflamasi pada bekas luka hipertrofik dan keloid. ${ }^{13,14} \mathrm{Hal}$ ini sangat baik untuk penanganan jerawat karena kebanyakan kasus pada proses penyembuhan jerawat disertai terbentuknya kerompeng dan scar. Disamping itu pegagan pernah diteliti mempunyai efek antibakteri terhadap Propionibakterium acnes dan menunjukkan hasil MIC (mg/dl) adalah 5 sedangkan MBC dalam $\mathrm{mg} / \mathrm{dl}$ adalah $>5 .{ }^{15}$ Pegagan pada konsenterasi $0.5 \%$ dikatakan telah mampu menyembuhkan luka dengan baik. ${ }^{16}$

Bentuk sediaan ikut berperan dalam keberhasilan penanganan jerawat. Sediaan dalam bentuk gel banyak digunakan karena sifat gel yang mudah menguap sehingga mudah mengering dan membentuk lapisan yang mudah dicuci, serta tidak mengandung minyak sehingga sediaan gel cocok untuk terapi topikal pada jerawat terutama penderita dengan tipe kulit berminyak karena tidak akan memperparah kondisi jerawat dan dapat mengurangi resiko timbulnya peradangan lebih lanjut akibat akumulasi minyak pada pori-pori kulit ${ }^{17}$

Manfaat daun kelor dan herba pegagan yang keduanya diyakini memiliki aktivitas sebagai antibakteri, antioksidan tinggi, anti inflamasi dan kemampuannya mempercepat penyembuhan luka sangat dibutuhkan untuk penatalaksanaan jerawat, namun pada penelitian tersebut kombinasi ekstrak daun kelor dan pegagan dalam bentuk sediaan kosmetik belum dilakukan sehingga data penelitian baik secara in vitro maupun in vivo kombinasi kedua tanaman tersebut juga belum ada. Oleh karena itu, penelitian ini bertujuan untuk menganalisa kombinasi ekstrak daun kelor (Moringa oleifera Lam.) dan herba pegagan (Centella asiatica (L.). Urb.) secara in vitro dan in vivo sebagai gel anti jerawat.

\section{METODE}

Penelitian ini melakukan dua jenis uji yaitu uji gel antijerawat secara in vitro dan in vivo. Jenis uji kedua menggunakan penelitian eksperimental dengan metode Randomized Control Trial. Variabel yang diukur adalah konsentrasi ekstrak, formula gel, parameter fisik dan kimia sebagai variabel independen, dan tingkat keparahan jerawat (komedo, papul, nodul, pustule, kista dan scar), dan sekresi sebum sebagai variabel dependen.

Populasi dalam penelitian ini adalah wanita usia 20 - 35 tahun yang menjadi pasien di klinik Duta Medika Bogor sebanyak 12 orang yang memenuhi kriteria inklusi dan eksklusi. Penentuan jumlah sampel berdasarkan penelitian in vivo sebelumnya yang dilakukan minimal pada 6 sukarelawan. Kriteria inklusi adalah wanita yang berusia 20 - 35 tahun yang menjadi pasien di klinik Duta Medika, Bogor, sehat, mempunyai kulit normal atau berminyak dan berjerawat pada area muka. Menghentikan penggunaan produk antijerawat lain 1 minggu sebelum dan selama penelitian dan bersedia mengikuti penelitian dengan menandatangani surat pernyataan setelah mendapat penjelasan (informed consent). Sedangkan kriteria eksklusi adalah wanita dengan kebiasaan merokok, mengkonsumsi alkohol, penderita dermatitis atopik dan pioderma, wanita hamil, pengguna obat kelompok anti inflamasi non steroid, androgen, kortikosteroid, penderita hiperandrogenisme dan pengguna kontrasepsi hormonal. 
Instrumen penelitia yang digunakan yakni Viscometer Brookfield sebagai parameter fisik untuk menentukan viskositas larutan dan oven yang akan digunakan untuk menguji stabilitas formula yang disimpan pada suhu $40^{\circ} \mathrm{C}$, selama 3 bulan; $\mathrm{pH}$ meter sebagai parameter kimia untuk menentukan $\mathrm{pH}$ gel; dan kondisi sebum, dengan alat skin analysis EH 900U sebagai parameter efektivitas. Data aktivitas antibakteri secara in vitro akan dianalisa dengan menggunakan uji paired test dengan $=5 \%$ untuk mengetahui pengaruh konsentrasi ekstrak daun kelor yang dikombinasikan dengan ekstrak pegagan terhadap pertumbuhan bakteri $P$. acnes. Data yang diperoleh akan diolah secara manual dan dengan bantuan komputer. Hasil pengolahan data akan disajikan dalam bentuk teks, tabel dan atau gambar.

Prosedur penelitian dilakukan dengan cara sebagai berikut: uji in vitro dilakukan dengan cara menguji antibakteri terhadap pertumbuhan bakteri $P$. acnesdengan dua metode yaitu cakram dan sumuran. Skrining ekstrak menggunakan metode cakram dan pengujian gel dari ekstrak tunggal daun kelor (Moringa oleifera Lam.), ekstrak tunggal herba pegagan (Centella asiatica (L.). Urb.) dan kombinasi ekstrak daun kelor (Moringa oleifera Lam.) dengan herba pegagan (Centella asiatica (L.). Urb.) menggunakan metode sumuran. Pengujian baik skrining maupun dalam bentuk sediaan gel digunakan kedua metode dan diambil hasil yang paling jelas. Sebagai kontrol positif digunakan tetrasiklin $1 \mathrm{mg} / \mathrm{ml}$. Hasil uji antibakteri yang menunjukkan diameter zona hambat minimal dipilih untuk dijadikan kombinasi ekstrak sediaan dalam bentuk gel. Gel dengan konsentrasi terpilih dilakukan uji parameter mutu fisik dan kimia, serta uji stabilitas selama 3 bulan pada 3 kondisi suhu. Gel dengan hasil stabilitas baik selanjutnya dilakukan uji keamanan dan manfaat secara in vivo.

Uji keamanan dilakukan kepada sukarelawan secara subjektif dengan menjawab beberapa pertanyaan dengan jawaban ya atau tidak dengan maksud agar sukarelawan tidak mengalami kesulitan dalam menjawab dan paham dengan apa yang dimaksud dalam pertanyaan tersebut. Secara objektif dilakukan dengan metode Repeated Opened Patch Test (ROPT) untuk mengetahui reaksi alergi dan iritasi. Uji manfaat dilakukan dengan cara melakukan uji klinis terhadap dua belas sukarelawan wanita usia 20 - 35 tahun dalam kurun waktu satu bulan sesuai dengan regenerasi kulit yang berlangsung kurang lebih 28 hari di Klinik Duta Medika. Parameter uji manfaat secara objektif dilakukan dengan mengevaluasi jenis kulit, tanda inflamasi, jumlah papule dan jumlah nodule yang diamati secara langsung dengan menggunakan magnifying lampu sedangkan produksi sebum dilakukan dengan alat skin analyzer high resolution EH - 990U 5MP. Uji manfaat juga dievaluasi secara subjektif dengan menjawab beberapa pertanyaan dengan jawaban ya atau tidak. Pertanyaan dibuat untuk mengetahui apakah pertumbuhan jerawat dipengaruhi faktor lain seperti riwayat dalam keluarga mempunyai gangguan jerawat, psikis, hormone menstruasi, mencoba beberapa produk kosmetik, dan kebersihan muka. Sebelum dilakukan pengujian in vivo, sukarelawan diberikan penjelasan dan menandatangani informed consent.

Ethical clearance pada penelitian ini diperoleh dari Fakultas Kedokteran Universitas Indonesia. Izin penelitian didapatkan dari Balai Penelitian Tanaman Aromatik (Balitro) Bogor untuk penapisan fitokimia, PT. Inticosmetic, Jakarta untuk formulasi gel dan pengujian organoleptik, fisik, kimia dan uji stabilitas, Q-Lab Fakultas Farmasi Universitas Pancasila untuk menguji in vitro aktivitas antibakteri, dan Klinik Duta Medika - Cileungsi - Bogor untuk melakukan uji keamanan dan manfaat.

\section{Hasil}

Pada penelitian ini, uji in vitro dilakukan untuk mengetahui aktivitas antibakteri ekstrak daun kelor dan ekstrak herba pegagan dalam menghambat pertumbuhan mikroba. Pengujian daya hambat dilakukan dengan dua metode yaitu metode cakram maupun sumuran. Diameter yang terbentuk termasuk diameter cakram. Pada metode cakram menggunakan diameter $6 \mathrm{~mm}$ dan pada konsentrasi $25 \%$ atau berat 25 gram kedua ekstrak menunjukkan hasil zona hambat $6 \mathrm{~mm}$ sehingga pada konsentrasi tersebut kedua ekstrak tidak mempunyai daya hambat terhadap bakteri. Uji diameter pada metode sumuran adalah $8 \mathrm{~mm}$ yang menunjukkan sebagai antibakteri sudah tidak memiliki daya hambat. Hasil penelitian menunjukkan pemeriksaan aktivitas antibakteri kedua ekstrak memiliki penghambatan terhadap mikroba $P$. Acnes pada konsentrasi pengenceran $\geq 50 \%$ pada berat ekstrak 1 gram. Ekstrak daun kelor pada konsentrasi pengenceran $50 \%$ dengan berat 1 gram atau 0,5 gram memiliki diameter daya hambat terhadap P.acne 8,4 mm dan herba pegagan pada konsentrasi yang sama dengan berat 0,5 gram mempunyai aktivitas antibakteri $10,6 \mathrm{~mm}$.

Studi in vitro ini juga menguji formula yang mempunyai daya hambat paling minimal dengan pembuatan gel kombinasi yang berisi ekstrak daun kelor dan ekstrak herba pegagan dalam empat formula dan perbandingan ekstrak 1:1 (Tabel 1). Hasil diameter daya hambat minimal setiap formula ditunjukkan Tabel 2.

Sediaan gel Kombinasi Ekstrak Daun Kelor dan Herba Pegagan (KEKP) yang baru dibuat dilakukan evaluasi gel yang memenuhi persyaratan fisika dan 
Tabel 1 Formula Gel KEKP

\begin{tabular}{lccccc}
\hline \multirow{2}{*}{ Bahan } & \multicolumn{5}{c}{ Formula ( gram ) } \\
\cline { 2 - 6 } & Fl & F2 & F3 & F4 & F5 \\
\hline Ekstrak daun kelor & - & 0,25 & 0,5 & 1 & 1,5 \\
Ekstrak herba pegagan & - & 0,25 & 0,5 & 1 & 1,5 \\
Carbopol 940 & 0,3 & 0,3 & 0,3 & 0,3 & 0,3 \\
TEA & 0,3 & 0,3 & 0,3 & 0,3 & 0,3 \\
Propilen glikol & 10 & 10 & 10 & 10 & 10 \\
Aquadest & $100 \mathrm{ml}$ & $100 \mathrm{ml}$ & $100 \mathrm{ml}$ & $100 \mathrm{ml}$ & $100 \mathrm{ml}$ \\
\hline
\end{tabular}

Tabel 2 Pemeriksaan aktivitas antibakteri F1, F2, F3, F4, F5 gel KEKP

\begin{tabular}{|c|c|c|c|c|c|c|c|c|c|c|}
\hline \multirow[b]{2}{*}{ 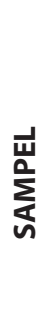 } & \multicolumn{2}{|c|}{$\begin{array}{c}\text { F1 } \\
\text { Kontrol (-) }\end{array}$} & \multicolumn{2}{|c|}{$\begin{array}{c}F 2 \\
0,25 \mathrm{gr} / \mathrm{mL}\end{array}$} & \multicolumn{2}{|c|}{$\begin{array}{c}\text { F3 } \\
0,5 \mathrm{~g} / \mathrm{mL}\end{array}$} & \multicolumn{2}{|r|}{$\begin{array}{c}F 4 \\
1 \mathrm{~g} / \mathrm{mL} \\
\end{array}$} & \multicolumn{2}{|c|}{$\begin{array}{c}F 5 \\
1,5 \mathrm{~g} / \mathrm{mL}\end{array}$} \\
\hline & 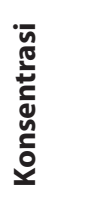 & 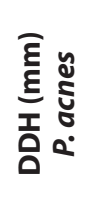 & 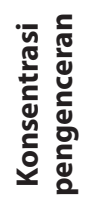 & 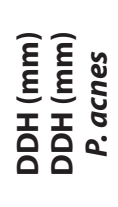 & 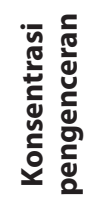 & 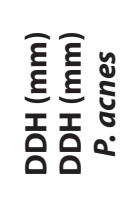 & 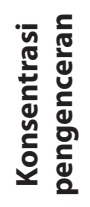 & 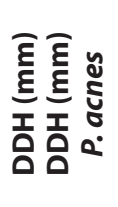 & 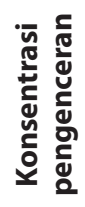 & 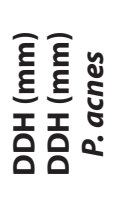 \\
\hline \multirow{9}{*}{ 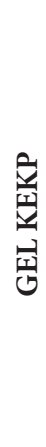 } & 100 & 8 & 100 & 8 & 100 & 8 & 100 & 8 & 100 & 24,6 \\
\hline & 50 & 8 & 50 & 8 & 50 & 8 & 50 & 8 & 50 & 19,9 \\
\hline & 25 & & & & & & & & & 17,1 \\
\hline & 12,5 & & & & & & & & & 16,8 \\
\hline & 6,25 & & & & & & & & & 15,6 \\
\hline & 3,125 & & & & & & & & & 13,7 \\
\hline & 1,56 & & & & & & & & & 11,6 \\
\hline & 0,78 & & & & & & & & & 10,4 \\
\hline & 0,078 & & & & & & & & & 8 \\
\hline
\end{tabular}

Tabel 3 Uji parameter fisika

\begin{tabular}{|c|c|c|c|c|c|c|c|c|c|c|c|}
\hline \multirow[b]{3}{*}{ Formula } & & \multicolumn{6}{|c|}{ Organoleptik } & \multicolumn{2}{|c|}{ Homogenitas } & \multicolumn{2}{|c|}{ Viskositas (Cps) } \\
\hline & & \multicolumn{3}{|c|}{ Blanko } & \multicolumn{3}{|c|}{ F5 } & \multirow[b]{2}{*}{ Blanko } & \multirow[b]{2}{*}{ F5 } & \multirow[b]{2}{*}{ Blanko } & \multirow[b]{2}{*}{ F5 } \\
\hline & & Warna & Bentuk & Bau & Warna & Bentuk & Bau & & & & \\
\hline \multirow{3}{*}{ Sampel } & I & & & & CJ & SP & $\mathrm{AK}$ & Homogen & Homogen & 340,62 & 311,40 \\
\hline & II & $\mathrm{J}$ & SP & $\mathrm{TB}$ & $\mathrm{CJ}$ & SP & $\mathrm{AK}$ & Homogen & Homogen & 340,04 & 310,99 \\
\hline & III & & & & $\mathrm{CJ}$ & SP & $\mathrm{AK}$ & Homogen & Homogen & 340,27 & 309,83 \\
\hline
\end{tabular}

J=Jernih, $\mathrm{CJ}=$ Coklat Jernih, $\mathrm{SP}=$ Semi Padat, $\mathrm{TB}=$ Tidak Berbau, $\mathrm{AK}=$ Aroma Khas

Tabel 4 Uji parameter kimia

\begin{tabular}{|c|c|c|c|}
\hline & & & \\
\hline & & Blanko & F5 \\
\hline & I & 4,53 & 5,67 \\
\hline Sampel & II & 4,65 & 5,71 \\
\hline & III & 4,60 & 5,75 \\
\hline Rata-rat & & 4,59 & 5,71 \\
\hline
\end{tabular}

kimia. Parameter yang digunakan untuk evaluasi secara organoleptik terhadap bentuk, warna, bau, adalah parameter fisika yang meliputi pemeriksaan homogenitas dan viskositas (Tabel 3), sedangkan 


\begin{tabular}{lc}
\hline Pengenceran & Jumlah koloni ( Cfu/gr) \\
\hline $10^{-1}$ & 0 \\
& 0 \\
$10^{-2}$ & 0 \\
& 0 \\
$10^{-3}$ & 0 \\
& 0 \\
$10^{-4}$ & 0 \\
& 0 \\
$10^{-5}$ & 0 \\
$10^{-6}$ & 0 \\
$10^{-7}$ & 0 \\
Kontrol Negatif & 0 \\
Kesimpulan & 0 \\
\end{tabular}

Tabel 6 Hasil uji keamanan pada kulit

\begin{tabular}{lcccc}
\hline & \multicolumn{3}{c}{ Sukarelawan } \\
\cline { 2 - 5 } Metode & & Iritasi & \multicolumn{2}{c}{ Alergi } \\
\hline \multirow{2}{*}{ ROPT } & $\mathrm{N}$ & $\%$ & $\mathrm{~N}$ & $\%$ \\
& 0 & 0,0 & 0 & 0,0 \\
\hline
\end{tabular}

Keterangan: $\mathrm{N}=$ jumlah relawan dengan respon positif

Tabel 7 Hasil uji manfaat gel KEKP

\begin{tabular}{|c|c|c|c|c|c|c|c|c|c|c|}
\hline \multirow[b]{2}{*}{ Sukarelawan } & \multicolumn{5}{|c|}{ Keadaan awal } & \multicolumn{5}{|c|}{ Keadaan akhir } \\
\hline & $\begin{array}{l}\text { Jenis } \\
\text { kulit }\end{array}$ & Komedo & $\begin{array}{l}\text { Papul/ } \\
\text { Pustul }\end{array}$ & Nodul & Score & $\begin{array}{l}\text { Jenis } \\
\text { kulit }\end{array}$ & Komedo & $\begin{array}{l}\text { Papul/ } \\
\text { Pustul }\end{array}$ & Nodul & Score \\
\hline IAN & Oily & 23 & 27 & 12 & 62 & Oily & 14 & 12 & 3 & 29 \\
\hline DMR & $\mathrm{N} / \mathrm{O}$ & 18 & 11 & 7 & 36 & $\mathrm{~N} / \mathrm{O}$ & 10 & 5 & 3 & 18 \\
\hline IRA & N/O & 13 & 8 & 15 & 36 & $\mathrm{~N} / \mathrm{O}$ & 7 & 4 & 9 & 20 \\
\hline IDN & $\mathrm{N} / \mathrm{O}$ & 25 & 50 & 3 & 78 & Oily & 14 & 18 & - & 32 \\
\hline MIR & Oily & 8 & 18 & 8 & 34 & Oily & 5 & 10 & 2 & 17 \\
\hline DPN & Oily & 7 & 15 & 12 & 34 & Oily & 5 & 7 & 4 & 16 \\
\hline VHT & $\mathrm{N} / \mathrm{O}$ & 3 & 8 & 12 & 23 & $\mathrm{~N} / \mathrm{O}$ & 3 & 2 & 3 & 8 \\
\hline EKT & $\mathrm{N} / \mathrm{O}$ & 10 & 40 & 4 & 54 & $\mathrm{~N} / 0$ & 6 & 11 & - & 17 \\
\hline NTR & N/O & 5 & 30 & 5 & 40 & $\mathrm{~N}$ & 3 & 13 & 2 & 18 \\
\hline MAR & Oily & 3 & 10 & 5 & 18 & Oily & 3 & 4 & 2 & 9 \\
\hline AHY & Oily & 8 & 15 & 15 & 38 & Oily & 2 & 6 & 4 & 12 \\
\hline RTR & $\mathrm{N} / \mathrm{O}$ & 8 & 5 & 10 & 23 & $\mathrm{~N} / \mathrm{O}$ & 3 & 2 & 3 & 8 \\
\hline
\end{tabular}

Keterangan: $\left(\right.$ Lehmann Grading System) $=$ Klasifikasi jerawat nilai total $<30=$ ringan, 30 s.d $125=$ sedang, $>125=$ berat $^{17}$

parameter kimia dievaluasi dengan pemeriksaan $\mathrm{pH}$ (Tabel 4). Uji cemaran mikroba yang dilakukan pada penelitian ini menunjukkan sediaan gel KEKP pada semua pengenceran menghasilkan angka
0 dengan kesimpulan hasil < 10Cfu/gr seperti yang ditunjukkan pada Tabel 5.

Uji in vivo gel antijerawat kombinasi KEKP ini dilakukan dengan uji keamanan dan manfaat yang 
melibatkan sukarelawan yang telah memenuhi kriteria inklusi dan ekslusi, Hasil uji kemanan gel yang dilakukan dengan metode Repeated Open Patch Test (ROPT) secara objektif pada dua belas sukarelawan tidak didapatkan reaksi alergi maupun iritasi pada saat pengolesan $1 \mathrm{jam}, 24 \mathrm{jam}$, maupun 48 jam pasca pengolesan KEKP (Tabel 6). Hasil pengamatan secara klinis terhadap komedo, jumlah papul - pustul, dan jumlah nodul yang telah dioles gel kombinasi selama 28 hari terbukti bermanfaat dalam memperbaiki derajat keparahan jerawat, seeperti yang ditunjukkan pada Tabel 7. Hasil uji secara objektif gel kombinasi KEKP, tetapi jenis kulit secara klinis tidak mengalami perubahan. Pengamatan pada 12 sukarelawan pada saat awal terdapat 9 orang dengan klasifikasi jerawat derajat sedang dan 3 orang dengan klasifikasi derajat ringan. Setelah dilakukan pengolesan gel kombinasi secara teratur setiap hari selama 28 hari, derajat tingkat keparahan pada sukarelawan berubah, sebanyak 11 sukarelawan dengan klasifikasi derajar ringan dan 1 orang sukarelawan dengan klasifikasi derajat sedang.

\section{DISKUSI}

Hasil penelitian skrining fitokimia menunjukkan bahwa ekstrak daun kelor dan herba pegagan mengandung senyawa metabolit sekunder yaitu alkaloid, saponin, tannin, fenolik, flavonoid, triterpenoid, steroid, dan glikosida. Hal ini membuktikan bahwa ekstrak daun kelor dan herba pegagan merupakan tanaman yang mempunyai kandungan antioksidan yang tinggi. . $8,9,14,15$ Kemampuan menghambat aktivitas bakteri didapatkan dari senyawa alkaloid, flavononoid, tannin, saponin, dan fenolik. ${ }^{1,4}$ Sedangkan kandungan steroid mampu mengurangi reaksi inflamasi yang menyertai jerawat. ${ }^{4}$ Kombinasi kandungan senyawa - senyawa dari kedua ekstrak dapat digunakan sebagai antijerawat dengan mekanisme kerja sesuai dengan etiopatogenesis jerawat yaitu melalui penghambatan bakteri Propionibacterium acnes (P. acnes), menekan proses inflamasi sehingga jumlah papul, pustul, nodul, rasa nyeri berkurang dan perubahan kadar sebum. ${ }^{1,4,5}$

Pada penelitian ini, uji in vitro dilakukan untuk mengetahui aktivitas antibakteri ekstrak daun kelor dan ekstrak herba pegagan dalam menghambat pertumbuhan mikroba. Metode pemeriksaan aktivitas antibakteri menggunakan sumuran dan cakram. Pada pengujian, penggunaan metode sumuran lebih dipertimbangkan dikarenakan pada metode cakram, dimana sampel berupa cairan semi gel, saat diletakkan diatas media menyebabkan difusi cairan ke dalam paper meluber dan mempengaruhi zona hambat yang terbentuk sehingga data yang digunakan adalah hasil dari pengujian dengan menggunakan metode sumuran dikarenakan zona yang terbentuk lebih jelas.

Dari hasil penelitian yang membuktikan bahwa kedua ekstrak mempunyai aktivitas antibakteri pada berat yang sama yaitu 0,5 gram, dilakukanlah uji percobaan formula kombinasi dengan berat dibawah nilai skrining dengan tujuan untuk mengetahui kemungkinan terjadinya efek sinergi jika kedua ekstrak dikombinasikan. Uji ini dilakukan dengan cara membuat gel kombinasi yang berisi ekstrak daun kelor dan ekstrak herba pegagan dalam empat formula dengan perbandingan ekstrak 1:1. Formula yang digunakan adalah formula dengan berat ekstrak 0,25 gram (F2), 0,5 gram (F3), 1 gram (F4), dan 1,5 gram (F5) dengan tujuan untuk mengetahui formula yang mempunyai daya hambat paling minimal (Tabel 1). Dari Tabel 2 didapatkan, F1 merupakan kontrol negatif yang berisikan gel yang tanpa berisi kedua ekstrak. Kontrol negatif digunakan untuk mengetahui ada tidaknya pengaruh basis gel terhadap pertumbuhan bakteri uji, sehingga dapat diketahui bahwa aktivitas yang ditunjukan oleh ekstrak ialah zat yang terkandung dalam sampel bukan berasal dari basis gel yang digunakan. Hasil diameter daya hambat pada kontrol negatif adalah $8 \mathrm{~mm}$ sehingga dapat dipastikan basis gel tidak mempunyai aktivitas sebagai antibakteri. Pada F2 dengan berat ekstrak lebih rendah dari skrining yaitu 0,25 gram membuktikan efek sinergi kedua ekstrak tidak terjadi dan menghasilkan diameter sumuran $8 \mathrm{~mm}$ sehingga dipastikan pada F1 tidak mempunyai daya hambat terhadap P. acnes. Pada pemeriksaan F2 dengan berat ekstrak sesuai dengan hasil skrining yaitu 0,25 gram ternyata pada saat dikombinasikan dalam bentuk gel tidak mempunyai efek sebagai antibakteri terhadap $P$. acnes, diameter daya hambat yang terbentuk adalah $8 \mathrm{~mm}$. Pada F3 dengan berat kedua ekstrak diperbesar menjadi 0,5 gram terbukti tidak memiliki aktivitas antibakteri terhadap $P$ acnes dengan diameter daya hambat yang dihasilkan adalah $8 \mathrm{~mm}$. Pada F4 dengan berat ekstrak diperbesar sampai dengan dua kali dari hasil skrining yaitu 1 gram tidak menunjukkan aktivitas antibakteri dengan hasil diameter daya hambat $8 \mathrm{~mm}$. F5 dengan berat kedua ekstrak sama yaitu masingmasing 1,5 gram pada pengenceran 0,78 mempunyai efek penghambatan terhadap bakteri $P$. acnes dengan diameter daya hambat minimalnya adalah $10,4 \mathrm{~mm}$. Hasil tersebut membuktikan bahwa berat sebenarnya dari kombinasi kedua ekstrak yang sudah mampu menunjukkan aktivitas 
antibakteri adalah 0,78 dari 3 gram yaitu sebesar 2,34 gram. Berat tersebut termasuk kandungan maltodextrin $10 \%$ sehingga berat murni kedua ekstrak yang sebenarnya adalah 2,11 gram.

Kedua ekstrak jika dalam bentuk ekstrak tunggal mempunyai aktivitas antibakteri yang berbeda saat dibuat dalam bentuk sediaan. ${ }^{15}$ Sebagai ekstrak tunggal dengan pengenceran $50 \%$ dengan berat ekstrak 1 gram menunjukkan aktivitas zona hambat, tetapi pada saat dalam bentuk gel zona hambat tidak terbentuk hal ini dikarenakan basis dari gel dapat mempengaruhi aktivitas bahan aktif pada ekstrak. Oleh karena itu, sediaan gel Kombinasi Ekstrak Daun Kelor dan Herba Pegagan (KEKP) yang baru dibuat dilakukan evaluasi gel. Evaluasi terhadap gel KEKP dapat diformulasi menjadi gel yang memenuhi persyaratan mutu fisika dan kimia. Gel KEKP pada uji stabilitas menunjukkan hasil yang stabil. Sediaan tetap homogen tidak ada perubahan bentuk, warna, dan bau. Pengujian viskositas gel sediaan yaitu dengan rentang antara 300-350 cPs. Sediaan gel memiliki rata-rata $\mathrm{pH} 5,71$. Hasil uji pH gel KEKP, dimana nilai $\mathrm{pH}$ tersebut sesuai dengan pH kulit yang berada pada rentang 4,5-6,5 sehingga gel dapat digunakan dengan aman pada kulit wajah dan tidak menimbulkan iritasi. Uji in vitro cemaran mikroba terhadap gel kombinasi ekstrak daun kelor dan herba pegagan menunjukkan angka lempeng total $<10 \mathrm{Cfu} / \mathrm{gr}$ sehingga gel tidak terkontaminasi oleh bakteri.

Penelitian in vivo gel antijerawat KEKP ini dilakukan dengan uji keamanan dan manfaat pada dua belas orang sukarelawan yang memenuhi kriteria inklusi yaitu berjenis kelamin wanita, berusia 25-35 tahun, belum menopause, tidak merokok, memiliki kulit yang sehat, tidak menderita dermatitis, tidak menderita penyakit kronis, dan bersedia untuk mengikuti penelitian hingga selesai. Gel kombinasi yang stabil diberikan kepada seluruh sukarelawan untuk digunakan selama 28 hari. Informed concern sudah diberikan sebelum dilakukan uji terhadap sukarelawan. Uji keamanan dilakukan dengan metode Repeated Open Patch Test (ROPT) dan dilakukan pengamatan pada 1, 24, 48, 72 jam di tempat yang telah dioles gel KEKP untuk mengetahui reaksi alergi maupun iritasi. Gel kombinasi terbukti aman pada dua belas sukarelawan dilanjutkan pengolesan secara teratur pagi dan sore selama 28 hari. Pengamatan dan penilaian dilakukan seminggu sekali dan dinilai secara keseluruhan pada hari ke 28. Gel kombinasi menunjukkan perbaikan klinis pada kedua belas sukarelawan dari jumlah komedo, papul - pustul dan nodul. ${ }^{15,17}$ Jenis kulit tidak berubah meskipun kondisi jerawat para sukarelawan sudah membaik.

\section{SIMPULAN}

Ekstrak serbuk dan gel kombinasi ekstrak daun kelor dan herba pegagan mempunyai aktivitas antibakteri terhadap Propinobacterium acnes. Pada saat dikombinasi dalam bentuk gel memerlukan berat yang lebih besar dibandingkan dalam bentuk serbuk tunggal yang hanya dilarutkan dengan NaCL. Gel yang mengandung kombinasi ekstrak daun kelor dan ekstrak herba pegagan dapat diformulasi menjadi gel yang memenuhi persyaratan mutu fisika dan kimia. Gel dengan kombinasi ekstrak daun kelor dan herba pegagan terbukti aman secara klinis terhadap sampel penelitian. Gel dengan kombinasi ekstrak daun kelor dan herba pegagan terbukti secara visual memperbaiki tingkat keparahan jerawat dan mampu secara laboratoris menurunkan kadar sebum. Penelitian ini masih banyak keterbatasan, sehingga besar harapan agar dapat menjadi dasar untuk dilakukan penelitian selanjutnya. Perlu dilakukan penelitian selanjutnya untuk mengetahui efek gel terhadap efek melembabkan, pengecilan pori-pori kulit dan elastisitas kulit setelah penggunaan gel ekstrak daun kelor dan herba pegagan. Pada penelitian selanjutnya, perlu ditambahkan parfum agar sediaan tidak berbau khas ekstrak, dan pengawet pada formula gel untuk menghindari kontaminasi mikroba.

\section{UCAPAN TERIMA KASIH}

Ucapan terima kasih penulis berikan kepada pasien klinik Duta Medika Bogor dan Program Magister Ilmu Farmasi Fakultas Farmasi Universitas Pancasila atas kesempatan dan bimbingan yang telah diberikan dalam penulisan penelitian ini.

\section{KONFLIK KEPENTINGAN}

Penulis menyatakan tidak terdapat konflik kepentingan (conflict of interest) pada penulisan laporan penelitian ini.

\section{PENDANAAN}

Penulis bertanggung jawab terhadap seluruh pembiayaan dalam pembuatan laporan penelitian ini.

\section{KONTRIBUSI PENULIS}

Penulis bertanggung jawab dalam pembuatan dan penulisan laporan penelitian ini. 


\section{DAFTAR PUSTAKA}

1. Eshtiaghi MN, Kuldiloke J. Formulation of anti acne cream containing natural antimicroba. International Research Journal Of Pharmacy. 2013;4(11):20-25.

2. Webster GF. Acne Vulgaris. BMJ. 2002;325(7362):475-9.

3. Well D. Acne vulgaris: A review of causes and treatment options. Nurse Pract. 2013;38(10):22-31

4. Strauss JS, Krowchuck DP, Leyden JJ, et al. Guidelines of care for acne vulgaris management. J Am Acad Dermatol. 2007;56(4):651-63

5. Sinha P, Srivastava S, Mishra N,et al. New perspectives on antiacne plant drugs : contribution to modern therapeutics. Biomed Res Int. 2014;2014:301304.

6. Ndhlala AR, Mulaudzi R, Ncube B, et al. Antioxidant, Antimicrobial and Phytochemical Variations in Thirteen Moringa oleifera Lam. Cultivars. Molecules. 2014;19(7): 10480-94

7. Leone A, Spada A, Battezzati A, et al. Cultivation, Genetic, Ethnopharmacology, Phytochemistry and Pharmacology of Moringa oleifera Leaves. Int J Mol Sci. 2015; 16(6):12791-835

8. Abalaka ME, Daniyan SY, Oyeleke SB, et al. The Antibacterial Evaluation of Moringa Oleifera Leaf Extracts on Selected Bacterial Pathogens. Journal of Microbiology Research. 2012;2(2):1-4

9. Marrufo T, Nazzaro F, Mancini E, et al. Chemical Composition and Biological Activity of the Essential Oil from Leaves of Moringa oleifera Lam. Cultivated in Mozambique. Molecules. 2013;18(9):10989-11000.

10. Ali A, Akhtar N, Khan. MS, et al. Effect of Moringa oleifera on undesireble skin sebum secretions of sebaceous glands observed during winter season in humans. Biomedical Research. 2013;24(1):127-130.
11. Samy RP, Chow VTK. Antimicrobial and Phytochemical Analysis of Centella asiatica (L.). Nature Precdings. 2011:1-6

12. Dash BK, Faruquee HM, Biswas SK, et al. Antibacterial and Antifungal Activities of Several Extracts of Centella asiatica L. against Some Human Pathogenic Microbes. Life Sciences and Medicine Research. 2011; LSMR-35

13. Oyedeji OA, Afolayan AJ. Chemical compotion and antibacterial activity of the Essential oil of centella asiatica. Growing in South Afrika. Journal Pharmaceutical Biology. 2005;(43):249-252.

14. Bylka W, Znajdek-Awiżeń P, Studzińska-Sroka E, Brzezińska M. Centella asiatica in cosmetology. Postep Derm Alergol. 2013;30(1):46-49

15. Chomnawang MT, Surassmo S, Nukoolkarn V, Gritsanapan W. Antimicrobial effects of Thai medicinal plants against acne-inducing bacteria. Journal of Ethnopharmacology. 2005;101(1-3):330-3.

16. Rismana E, Rosidah I, Prasetyawan Y, Bunga O, Erna Y. Efektivitas Khasiat Pengobatan Luka Bakar Sediaan Gel Mengandung Fraksi Ekstrak Pegagan Berdasarkan Analisis Hidroksiprolin Dan Histopatologi Pada Kulit Kelinci. Bul. Penelit. Kesehat, 2013;41(1):45-60.

17. Wasitaatmadja SM. Manifestasi klinis, klasifikasi, dan stadium akne. National Symposium and Workshop in Cosmetic Dermatology. Acne: New concept and challenges. Jakarta. 2010

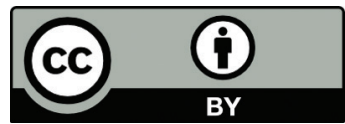

This work is licensed under a Creative Commons Attribution 